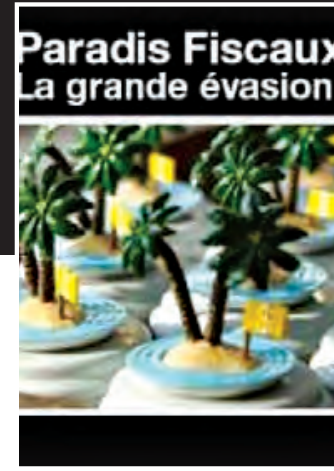

TÍTULO ORIGINAL,

"Paradis fiscaux, la grande évasion",

AÑO: 2008, DURACIÓN: 53 minutos,

PAÍS: Francia,

DIRECTOR: Frederic Brunquel,

GUIÓN: Frederic Brunquel,

GÉNERO, Documental, Mediometraje.

\title{
Paraísos Fiscales: La Gran Evasión
}

Este documental francés trata sobre los paraísos fiscales a nivel global y su repercusión en desarrollo de un auténtico estado de bienestar en todo el mundo. Es ilustrativa la cifra mencionada al inicio: la ONU necesita 40 mil millones de euros durante cinco años para erradicar la pobreza del mundo, los cuales no encuentra por ninguna parte; dicha cifra está representada en apenas el $0,5 \%$ de un total de los depósitos privados desviados a paraísos fiscales.

Su exposición inicia con la presentación del paraíso fiscal en la isla de Jersey en el Canal de La Mancha, donde todo mundo es banquero o contable, y con un elemento ético indispensable: la discreción. Allí menciona que la pequeña comunidad gestiona un depósito total de 800 mil millones de Euros, lo cual duplica el presupuesto total de Francia. A través de este ejemplo, el autor nos presenta cómo a través de un sistema de hombres de paja, que hacen las veces de representantes de las más diversas com. pañías a nivel mundial.

De ese ejemplo crucial comienza un detallado despliegue de los distintos paraísos fiscales a nivel mundial, donde contabiliza 72, con la probabilidad de que Ghana sea el número 73. De estos nos advierte los siguientes síntomas: países pequeños, abundancia de bancos, leyes concesivas a los inversores extranjeros, el secreto bancario como una máscara de la protec. ción de datos, sociedades offshore, etc. Todos estos elementos legitimados en una maraña de leyes, tratados y bancos internacionales, de tal manera que dichas prácticas no pueden considerarse ilegales en un sentido técnico. De todo lo anterior, el autor aboga por denunciar el sentido ético del que carecen estas prácticas.

El documental no propone la solución en la medida en que no es fácil hacer un tratamiento generalizado que componen estas prácticas; sin em- 
bargo, nos advierte de sus terribles consecuencias: le llama el talón de Aquiles y la Bestia Negra del Capitalismo; el monstruo que espantará al ciudadano común quien al continuar pagando esa factura, para equilibrar la inversión estatal, terminará por perder la confianza en todos los bancos; en síntesis, lo caracteriza como el mayor impedimento para que el mundo siga avanzando en su desarrollo.

Su contenido es accesible para el espectador no especializado y constituye una herramienta útil para informar a la población en general. Recomenda. do para estudiantes y académicos. 